\author{
ALEKSANDER JAKUBOWSKI \\ ORCID: 0000-0002-5937-9591 \\ Uniwersytet Warszawski
}

\title{
WPIS URZĘDNIKÓW NA LISTĘ RADCÓW PRAWNYCH - ZAGADNIENIA PROBLEMOWE
}

\begin{abstract}
Abstrakt: Przedmiotem artykułu są kwestie problemowe dotyczące przepływu osób zatrudnionych w administracji publicznej do samorządu radców prawnych. Stan prawny odnoszący się do regulacji wpisu na listę radców prawnych osób wykonujących czynności wymagające wiedzy prawniczej w urzędach organów władzy publicznej nie jest zadowalający. Występują rozbieżności co do rozumienia pojęcia „zatrudnienia”, jak też wątpliwości wzbudza sama kategoria „urzędy organów władzy publicznej”. Ponadto sposób ujęcia w przepisach przesłanek wpisu na listę radców prawnych omawianej kategorii osób trudno uznać za w pełni urzeczywistniający ideały określoności i precyzji prawa. Stan ten nie współgra z wymogami art. 2 i art. 17 ust. 1 Konstytucji. De lege ferenda wydaje się zasadne umożliwienie wpisu na listę radców prawnych bez potrzeby weryfikacji w formie egzaminu radcowskiego osób, które mają stopień naukowy doktora nauk prawnych i istotne, wieloletnie doświadczenie zawodowe w instytucjach publicznych na stanowiskach związanych z bieżącym stosowaniem prawa administracyjnego.
\end{abstract}

Słowa kluczowe: samorząd zawodowy, dostęp do zawodu, urzędnicy, radcowie prawni

\section{WSTĘP}

Przedmiotem niniejszego opracowania są kwestie problemowe dotyczące przepływu osób zatrudnionych w administracji publicznej do samorządu radców prawnych. $\mathrm{Z}$ trudnościami na tym tle mierzą się organy administracji publicznej (zarówno samorządu radcowskiego, jak i minister sprawiedliwości), sądy administracyjne, Trybunał Konstytucyjny oraz nauka prawa. $Z$ tego względu podjęta analiza ma znaczenie nie tylko teoretyczne, lecz także dla praktyki stosowania prawa.

Za główne regulacje normatywne z perspektywy tytułowej problematyki uznać należy przede wszystkim art. 25 ust. 1 pkt 4 lit. c i pkt 5 lit. c ustawy z dnia 6 lipca 1982 roku o radcach prawnych ${ }^{1}$. Zgodnie z nimi wymogu odbycia aplikacji radcowskiej i złożenia egzaminu radcowskiego nie stosuje się do osób, które zdały egzamin sędziowski lub prokuratorski po dniu 1 stycznia 1991 roku lub egzamin

1 Tekst jedn. Dz.U. z 2020 r. poz. 75 (dalej: u.r.p.). 
notarialny po dniu 22 kwietnia 1991 roku lub mają stopień naukowy doktora nauk prawnych oraz w okresie 5 lat przed złożeniem wniosku o wpis na listę radców prawnych, łącznie przez co najmniej 3 lata, były zatrudnione w urzędach organów władzy publicznej lub w państwowych jednostkach organizacyjnych i wykonywały wymagające wiedzy prawniczej czynności bezpośrednio związane z tworzeniem projektów ustaw, rozporządzeń lub aktów prawa miejscowego.

Kolejno zwrócić należy uwagę na art. 25 ust. 2 pkt 4 i 4a u.r.p., zgodnie z którym do egzaminu radcowskiego składanego przed komisją do przeprowadzenia egzaminu radcowskiego bez odbycia aplikacji radcowskiej mogą przystąpić osoby, które po ukończeniu wyższych studiów prawniczych albo aplikacji legislacyjnej przez okres co najmniej 4 lat w okresie nie dłuższym niż 6 lat przed złożeniem wniosku o dopuszczenie do egzaminu były zatrudnione w urzędach organów władzy publicznej i wykonywały odpowiednio wymagające wiedzy prawniczej czynności bezpośrednio związane, po pierwsze, ze świadczeniem pomocy prawnej na rzecz tych urzędów lub, po drugie, z tworzeniem projektów ustaw, rozporządzeń lub aktów prawa miejscowego.

Już na wstępie należy zaznaczyć, że poczynione w niniejszym opracowaniu rozważania mają charakter ogólnosystemowy; analogiczne regulacje odnajdzie się w art. 66 ust. 1 pkt 4 lit. c i pkt 5 lit. c oraz ust. 2 pkt 4 i 4a ustawy z dnia 26 maja 1982 roku - Prawo o adwokaturze ${ }^{2}$ (odnośnie do wpisu na listę adwokatów) czy w art. $12 \S 2$ pkt 4 i 5 ustawy z dnia 14 lutego 1991 roku - Prawo o notariacie ${ }^{3}$ (względem przystąpienia do egzaminu notarialnego bez odbycia aplikacji notarialnej). Stąd poczynione tezy znajdują odpowiednie odniesienie również do tych przepisów, jak też są formułowane $\mathrm{z}$ uwzględnieniem ich treści i powstałego na ich gruncie orzecznictwa.

Zakres badań ogniskuje się wokół czterech podstawowych zagadnień problemowych. Po pierwsze, rozumienia pojęcia „zatrudnienie” użytego przez ustawodawcę we wskazanych przepisach. Po drugie, kwestii tego, jakie podmioty można zaliczyć do „urzędów organów władzy publicznej”. Po trzecie, odpowiedzi na pytanie, jak należy rozumieć pojęcie „czynności bezpośrednio związanych z tworzeniem projektów ustaw, rozporządzeń lub aktów prawa miejscowego" oraz „czynności bezpośrednio związanych ze świadczeniem pomocy prawnej na rzecz urzędów”. Po czwarte, zakresu weryfikacji doświadczenia osoby ubiegającej się o wpis „w wykonywaniu czynności wymagających wiedzy prawniczej”.

\section{POJĘCIE „ZATRUDNIENIE”}

Pierwszy z analizowanych problemów dotyczy pojęcia „zatrudnienie”. Wątpliwości budzi, czy w jego zakres na gruncie u.r.p. wchodzi wykonywanie pracy

2 Tekst jedn. Dz.U. z 2019 r. poz. 1513 ze zm.

3 Tekst jedn. Dz.U. z 2019 r. poz. 540 ze zm. 
na podstawie stosunku zlecenia, czy wyłącznie stosunku pracy. Na tym tle wyróżnić wypada dwa przeciwstawne stanowiska.

Przede wszystkim odnotować należy nurt orzeczniczy opowiadający się za szerokim rozumieniem pojęcia „zatrudnienia”. Opiera się on na założeniu, że przepisy u.r.p. ustanawiają w świetle art. 65 ust. 1 zd. drugie Konstytucji ograniczenie wolności wykonywania zawodu. W konsekwencji, jako wyjątek od konstytucyjnej zasady, ograniczenie to nie może być kształtowane w drodze rozszerzającej wykładni norm określających przesłanki warunkujące wpis. Tym samym argumentuje się, że „Jakkolwiek [...] ustawodawca wprowadza przesłankę »zatrudnienia«, to nie czyni zastrzeżenia, że zatrudnienie może być wykonywane wyłącznie w stosunku pracy (na podstawie umowy o pracę)"4. W ocenie NSA art. 25 ust. 2 pkt 3 u.r.p. świadczy o tym, że gdy ustawodawca ma na myśli umowę o pracę, wówczas wskazuje to wyraźnie, czego nie czyni w pkt 4 tego przepisu. Jednocześnie NSA sygnalizuje, że w obrocie prawnym wyróżnia się pojęcia pracowniczego i niepracowniczego zatrudnienia ${ }^{5}$, w kontekście czego wykonywanie czynności na podstawie umów cywilnoprawnych może być zatrudnieniem. Doprowadziło to NSA do wniosku, że zawarte w art. 25 ust. 2 pkt 4 u.r.p. pojęcie ,zatrudnienie" nie odnosi się jedynie do wykonywania pracy na podstawie stosunku pracy. Ponadto sąd zwrócił uwagę, że w myśl art. 8 ust. 5 u.r.p., ilekroć w ustawie jest mowa o „stosunku pracy”, „,zatrudnieniu”, „wynagrodzeniu”, rozumie się przez to również odpowiednio „stosunek służbowy”, ,pełnienie służby” i „,uposażenie”. Zdaniem NSA regulacja ta przemawia za przyjęciem, że ustawodawca opowiada się za szerokim rozumieniem omawianego zwrotu w u.r.p. ${ }^{6}$ Odmienne zapatrywanie przedstawia R. Stankiewicz. W jego ocenie, dokonując wykładni pojęcia „zatrudnienie”, należy odnieść się do systemu prawa, gdyż u.r.p. nie definiuje tego pojęcia i nie nakazuje jego rozumienia w sposób specyficzny, właściwy tylko sprawom o wpis na listę radców prawnych; odwołanie się zaś do definicji tego pojęcia w innej gałęzi prawa pozwala zachować spójność i jednolitość systemu prawnego oraz zwrotów w nim obowiązujących. W rezultacie pojęcie „zatrudnienie” należy rozumieć zgodnie z art. 2 k.p. ${ }^{7}$, to jest jako zatrudnienie na podstawie umowy o pracę, powołania, wyboru, mianowania lub spółdzielczej umowy o pracę. Autor ten zaznacza ponadto, że skoro ustawodawca w u.r.p. nie zdefiniował omawianego pojęcia, a jednocześnie w tej samej jednostce redakcyjnej, to jest art. 25 u.r.p., różnicuje wykonywanie czynności wymagających wiedzy prawniczej na podstawie umów cywilnoprawnych i zatrudnienia, to nie ma podstaw, aby pojęcie „zatrud-

${ }^{4}$ Tak wyrok WSA w Warszawie z 18 kwietnia 2018 roku, VI SA/Wa 150/18. To i następne powoływane orzeczenia sądów administracyjnych dostępne w Centralnej Bazie Orzeczeń Sądów Administracyjnych, http://orzeczenia.nsa.gov.pl.

5 Więcej zob. M. Gersdorf, Prawo zatrudnienia, Warszawa 2013, s. 75 n.; I. Nowak, R. Bucholski, Dostęp doktorów nauk prawnych do zawodów prawniczych - wybrane problemy, ,Zeszyty Naukowe Sądownictwa Administracyjnego" 2015, nr 6, s. 57-63.

${ }^{6}$ Zob. wyrok NSA z dnia 9 kwietnia 2019 roku, II GSK 1721/18.

7 Tekst jedn. Dz.U. z 2019 r. poz. 1040 ze zm. 
nienie" rozumieć szerzej, niż wynika to z kodeksu pracy, i kwalifikować osoby wykonujące czynności na podstawie umowy cywilnoprawnej jako „zatrudnione”. R. Stankiewicz akcentuje, że stosunek zlecenia, jako umowa cywilnoprawna, nie jest regulowany przepisami prawa pracy, wobec czego w jego ocenie nie może być uważany za zatrudnienie. Podnosi on, że przeciwne twierdzenie byłoby wykładnią rozszerzającą, niedopuszczalną $\mathrm{w}$ myśl zasady exceptiones non sunt extentendae ze względu na charakter analizowanych przepisów, gdyż wprowadzają one wyjątek od zasady, że wpis na listę radców prawnych wymaga odbycia aplikacji radcowskiej i złożenia egzaminu radcowskiego, stąd muszą one podlegać ścisłej wykładni ${ }^{8}$. Taki też pogląd zakazujący rozszerzającej wykładni wspomnianych wyjątków prezentowany jest $\mathrm{w}$ drugim nurcie orzecznictwa ${ }^{9}$, w tym Naczelnego Sądu Administracyjnego ${ }^{10}$.

Ów drugi nurt zasługuje na podzielenie, trudno bowiem odmówić trafności argumentom za jego słusznością. Tezę, że przez „zatrudnienie” na gruncie u.r.p. nie można potraktować wykonywania umowy cywilnoprawnej zlecenia, poprzeć można jeszcze dalszymi racjami.

Przede wszystkim na przedstawiany kierunek wykładni — podzielany we wcześniejszym orzecznictwie ${ }^{11}$ — wskazują przepisy określające dokumenty przedkładane na okoliczność wykazania „zatrudnienia”. Jest to świadectwo pracy lub zaświadczenie o zatrudnieniu ${ }^{12}$. Tymczasem w wypadku wniosku opartego na doświadczeniu uzyskanym w kancelarii prawnej jest to świadectwo pracy lub zaświadczenie o zatrudnieniu albo umowy cywilnoprawne ${ }^{13}$. W odniesieniu do notariatu wynika to wprost z przepisu rangi ustawowej — art. 74a $\S 4$ pkt 7 Prawa o notariacie ${ }^{14}$ — którego nie można pominąć przy wykładni systemowej. Zgodnie z $\S 10$ Zasad techniki prawodawczej do oznaczenia jednakowych pojęć używa się jednakowych określeń, a różnych pojęć nie oznacza się tymi samymi określe-

${ }^{8}$ R. Stankiewicz, [w:] Ustawa o radcach prawnych. Komentarz, red. T. Scheffler, Warszawa 2018, s. 439-441.

9 Zob. wyrok WSA w Warszawie z dnia 9 czerwca 2010 roku, VI SA/Wa 571/10; wyrok WSA w Warszawie z dnia 9 listopada 2017 roku, VI SA/Wa 1173/17.

10 Zob. wyrok NSA z dnia 14 lutego 2019 roku, II GSK 5672/16.

11 Zob. wyrok WSA w Warszawie z dnia 17 lipca 2013 roku, VIII SA/Wa 380/13.

12 Zob. na przykład § 5 ust. 4 i 6 rozporządzenia Ministra Sprawiedliwości z dnia 17 grudnia 2013 roku w sprawie przeprowadzania egzaminu radcowskiego, tekst jedn. Dz.U. z 2016 r. poz. 116. Podobnie $\S 5$ ust. 4 i 6 rozporządzenia Ministra Sprawiedliwości w sprawie przeprowadzania egzaminu adwokackiego, Dz.U. z 2016 r. poz. 112.

13 Zob. § 5 ust. 3 rozporządzenia Ministra Sprawiedliwości z dnia 17 grudnia 2013 roku w sprawie przeprowadzania egzaminu radcowskiego. Por. też art. 74a $\S 4$ pkt 7, pkt $8 \mathrm{a}$ i pkt $8 \mathrm{~b}$ ustawy - Prawo o notariacie.

14 „Osoby, o których mowa w art. $12 \S 2-2$ b, dołączają do wniosku odpowiednio dokumenty zaświadczające co najmniej 4-letni okres zatrudnienia w Rzeczypospolitej Polskiej lub wykonywania na podstawie umów cywilnoprawnych w kancelarii notarialnej w Rzeczypospolitej Polskiej wymagających wiedzy prawniczej czynności bezpośrednio związanych z czynnościami wykonywanymi przez notariusza". 
niami ${ }^{15}$. Konsekwentnie umowa cywilnoprawna - umowa zlecenia — nie jest środkiem dowodowym potwierdzającym zatrudnienie w administracji publicznej. Lege distinguente. Odmienna wykładnia prowadzi do zaburzenia jednolitości systemu prawa.

Należy też zauważyć, że - wbrew przytoczonemu stanowisku NSA ${ }^{16}$ art. 8 ust. 5 u.r.p. wyklucza uznanie za zatrudnienie wykonywania czynności na podstawie umowy zlecenia. Przepis ten określa bowiem, że przez zatrudnienie należy rozumieć także pełnienie służby. Mając na względzie założenie o racjonalności ustawodawcy, trzeba przyjąć, że gdyby chciał objąć pojęciem zatrudnienia także „odmianę" niepracowniczą opartą na umowie zlecenia, to uczyniłby w tym właśnie przepisie. Takiego zabiegu prawodawca jednak nie dokonał. Przeciwnie, zrównuje w nim z zatrudnieniem pełnienie służby, a zatem relację szczególnej podległości przeciwną umowie zlecenia.

Zatrudnienie w urzędzie organów administracji publicznej cechuje się zasadniczo większym podporządkowaniem (podleganiem kierownictwu) niż w przypadku świadczenia usług na rzecz radcy prawnego $\mathrm{w}$ ramach umowy zlecenia ${ }^{17}$. Zatem zróżnicowanie osób ubiegających się o wpis w zależności od formy, na podstawie której dokonują oni relewantnych czynności, nie narusza zasady równości (art. 32 Konstytucji). Na omawiane rozróżnienie wskazał też TK. W wyroku z dnia 30 listopada $2011 \mathrm{roku}^{18}$, porównując podstawy wpisu w postaci ,zatrudnienia” i ,wykonywania czynności na podstawie umowy o pracę lub umowy cywilnoprawnej”, podniósł, że w pierwszym przypadku spełnienie warunku przystąpienia do egzaminu bez odbycia aplikacji zależy od długości „okresu zatrudnienia” wskazanego w świadectwie pracy lub zaświadczeniu o zatrudnieniu, w drugim — od długości okresu wykonywania czynności wynikającego z umowy cywilnoprawnej. Pamiętać zaś należy, że przyjmowane przez ustawodawcę rozwiązania muszą zapewniać równe traktowanie osób wykonujących poszczególne zawody prawnicze lub aspirujących do ich wykonywania, jak też unikać rozwiązań sprzyjających omijaniu prawa ${ }^{19}$.

W tym kontekście nie sposób jednak pominąć innego rodzaju nierówności między urzędnikami a osobami wykonującymi na podstawie umowy o pracę lub umowy cywilnoprawnej wymagające wiedzy prawniczej czynności bezpośrednio związane ze świadczeniem pomocy prawnej przez adwokata lub radcę prawnego. Mianowicie przesłanka wpisu na listę radców prawnych bez wymogu odbycia aplikacji radcowskiej i złożenia egzaminu radcowskiego obejmuje tylko urzędników związanych bezpośrednio z legislacją (art. 25 ust. 1 pkt 4 lit. c i pkt 5 lit. c

15 Załącznik do rozporządzenia Prezesa Rady Ministrów z dnia 20 czerwca 2002 roku w sprawie Zasad techniki prawodawczej, tekst jedn. Dz.U. z 2016 r. poz. 283 ze zm.

16 Zob. wyrok NSA z dnia 9 kwietnia 2019 roku, II GSK 1721/18.

17 Por. I. Nowak, R. Bucholski, op. cit., s. 62, 65.

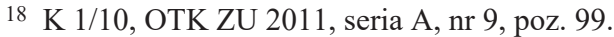

19 Zob. wyrok TK z dnia 8 listopada 2006 roku, K 30/06, OTK ZU 2006, seria A, nr 10, poz. 149. 
u.r.p.), pozostawiając poza zakresem tego przepisu urzędników wykonujących wymagające wiedzy prawniczej czynności bezpośrednio związane ze świadczeniem pomocy prawnej odpowiadające czynnościom wykonywanym przez osoby, o których mowa w art. 25 ust. 1 pkt 4 lit. b i pkt 5 lit. b u.r.p. O ile zróżnicowanie polegające na wymaganiu od osób wykonujących czynności w urzędach organów administracji publicznej ściślejszego stosunku podporządkowania (zatrudnienia w ramach stosunku pracy) — jak wskazano - może być uznane za usprawiedliwione, to dla przedstawionej odmienności odnoszącej się do zakresu wykonywanych czynności trudno znaleźć uzasadnienie. Nie zachodzi wszak istotna różnica między wykonywaniem wymagających wiedzy prawniczej czynności w ramach pracy na rzecz radcy prawnego (zespołu radców prawnych) w urzędzie a wykonywaniem tożsamych czynności w związku ze świadczeniem pomocy prawnej przez radcę prawnego na przykład w ramach kancelarii. Brakuje tu wymaganej cechy relewantnej różnicującej obie kategorie podmiotów podobnych ${ }^{20}$, co prowadzi do wniosku o naruszeniu w tym zakresie zasady równości ujętej w art. 32 Konstytucji. Co więcej, ekwiwalentność czynności bezpośrednio związanych ze świadczeniem pomocy prawnej na rzecz urzędów oraz przez radcę prawnego lub adwokata działającego w ramach kancelarii prawnej uznał ustawodawca w przypadku przesłanek dopuszczenia do egzaminu radcowskiego bez konieczności odbycia aplikacji (por. art. 25 ust. 2 pkt 3-4a u.r.p.). De lege ferenda należy zatem postulować usunięcie wskazanej nierówności w obrębie art. 25 ust. 1 u.r.p., na przykład przez dodanie kategorii zbliżonej do art. 25 ust. 2 pkt 4 u.r.p.

\section{URZĘDY ORGANÓW WŁADZY PUBLICZNEJ}

Pojęcie „urzędy organów władzy publicznej” nie zostało w prawie zdefiniowane. Pojawia się ono w art. 1 pkt 2 ustawy z dnia 12 grudnia 1997 roku o dodatkowym wynagrodzeniu rocznym dla pracowników jednostek sfery budżetowej ${ }^{21}$, w którym odróżnia się tę kategorię od urzędów organów kontroli (na przykład NIK), organów ochrony prawa (na przykład RPO, RPD) czy sądów i trybunałów. Tymczasem w ustawie z dnia 27 sierpnia 2009 roku $^{22}$ o finansach publicznych organy administracji rządowej, organy kontroli państwowej i ochrony prawa oraz sądy i trybunały określa się łącznie mianem organów władzy publicznej (zob. art. 9 pkt 1), odróżniając od nich jednak na przykład agencje wykonawcze czy niektóre fundusze. Uwzględnienie wykładni systemowej na podstawie ustaw nie daje zatem zadowalających rezultatów.

${ }^{20}$ Zob. M. Ziółkowski, Zasada równości w prawie, „Państwo i Prawo” 2015, nr 5, s. 96, 99, 110.

21 Tekst jedn. Dz.U. z 2018 r. poz. 1872 ze zm.

22 Tekst jedn. Dz.U. z 2019 r. poz. 869 ze zm. 
Z tych względów, aby ustalić znaczenie pojęcia „urząd organu władzy publicznej" w omawianym kontekście, pożądane wydaje się wykorzystanie przede wszystkim dorobku wypracowanego w odniesieniu do rozumienia kategorii „organy władzy publicznej”. Warto w szczególności sięgnąć do Konstytucji, która w art. 7 stwierdza, że właśnie „organy władzy publicznej działają na podstawie i w granicach prawa". W orzecznictwie wskazuje się, że mieszczą się w tym pojęciu wszystkie organy państwowe, bez względu na ich klasyfikację jako organy sprawujące władzę ustawodawczą, wykonawczą lub sądowniczą czy pozostające poza tym trójpodziałem, a także niezależnie od właściwości ogólnopaństwowej czy terytorialnie ograniczonej ${ }^{23}$. W przypadku tych ostatnich nie ma znaczenia ani szczebel, ani czy jednostka ma charakter główny, czy pomocniczy. Do tego pojęcia zaliczają się wszelkie organy dysponujące kompetencjami władczymi, zarówno państwowe, samorządowe (w tym samorządu zawodowego), jak i inne, którym przepisy prawa takie kompetencje (władztwo publiczne) powierzają ${ }^{24}$.

Z kolei pojęcie „urząd” odnosi się do określonej jednostki organizacyjnej $z$ towarzyszącym jej substratem osobowym i rzeczowym ${ }^{25}$. Na gruncie u.r.p. wydaje się usprawiedliwione rozumienie pojęcia „urząd” zarówno jako organu, jak i jego aparatu pomocniczego. Nie byłoby uzasadnione rygorystyczne przyjmowanie, że „urząd" to wyłącznie aparat pomocniczy organu administracji publicznej ${ }^{26}$, gdyż wówczas powstać mogłyby wątpliwości, czy w zakres pojęcia wchodzi sam piastun obsługiwanego organu, który przecież też może być zainteresowany wpisem na listę radców prawnych.

Spośród „nieklasycznych podmiotów” za urząd organu władzy publicznej zostały uznane Krajowa Izba Odwoławcza ${ }^{27}$, Narodowe Centrum Badań i Rozwo$\mathrm{ju}^{28}$, jak też urząd obsługujący Krajową Radę Doradców Podatkowych ${ }^{29}$. Do tej kategorii nie zostały zaliczone spółki w rozumieniu kodeksu spółek handlowych, choćby z udziałem podmiotów publicznych ${ }^{30}$.

Należy zaznaczyć, że niedopuszczalne jest uznawanie za urzędy organów władzy publicznej, na zasadach analogii, podmiotów innego rodzaju, w których

23 Zob. wyrok WSA w Warszawie z dnia 12 stycznia 2018 roku, VI SA/Wa 628/17.

24 Zob. wyrok WSA w Warszawie z dnia 5 lipca 2019 roku, VI SA/Wa 578/19.

25 Zob. M. Stahl, Zagadnienia ogólne, [w:] System Prawa Administracyjnego, t. 6. Podmioty administrujące, red. R. Hauser, Z. Niewiadomski, A. Wróbel, Warszawa 2011, s. 65.

${ }^{26}$ Zob. wyrok NSA z dnia 3 stycznia 2008 roku, I FSK 116/07.

27 Zob. wyrok WSA w Warszawie z dnia 6 czerwca 2018 roku, VI SA/Wa 397/18 (nieprawomocny).

28 Zob. wyrok WSA w Warszawie z dnia 29 maja 2019 roku, VI SA/Wa 264/19. Pogląd ten należy zaaprobować w świetle doktryny — zob. P. Wajda, A. Wiktorowska, Agencje administracyjne, [w:] System Prawa Administracyjnego, t. 6, s. 407.

29 Zob. wyrok WSA w Warszawie z dnia 5 lipca 2019 roku, VI SA/Wa 578/19.

30 Zob. wyrok WSA w Warszawie z dnia 6 czerwca 2018 roku, VI SA/Wa 397/18 (nieprawomocny). 
wykonuje się podobne czynności. Dlatego za pracę w urzędzie organu władzy publicznej nie może być uznana na przykład aplikacja sędziowska ${ }^{31}$.

Dodać też warto, że staż w urzędach organów władzy publicznej nie musi być odbyty w jednym urzędzie, krytycznie jednak należy ocenić praktykę łączenia wymiarów stażu w odniesieniu do odmiennych przesłanek (podstaw) wpisu na listę radców prawnych, nie ma bowiem ku niej podstawy prawnej ${ }^{32}$. Godzi ona w gwarancje profesjonalizmu, jakie ma dawać odpowiednio długi staż w określonej przez ustawodawcę kategorii podmiotów. Jeżeli wolą ustawodawcy było sumowanie okresów wymienionych dla odmiennych podstaw wpisu, powinien to określić wprost w przepisach, czego nie uczynił.

\section{CZYNNOŚCI BEZPOŚREDNIO ZWIĄZANE ZE ŚWIADCZENIEM POMOCY PRAWNEJ NA RZECZ URZĘDÓW}

Odnosząc się do pojęcia „czynności bezpośrednio związane ze świadczeniem pomocy prawnej na rzecz urzędów” i czynności „,związane z tworzeniem projektów ustaw, rozporządzeń lub aktów prawa miejscowego", nie sposób pominąć orzecznictwo $\mathrm{TK}^{33}$. Wytknął on względem kontrolowanej wówczas regulacji odnośnie do pojęcia „stanowisk związanych ze stosowaniem lub tworzeniem prawa”, że nie określa ono rodzaju wzmiankowanej „więzi” („związania”) stanowiska z rozległymi i złożonymi procesami „tworzenia” oraz „stosowania” prawa. Jak wskazał TK, określenie to nie precyzuje, czy chodzi o udział merytoryczny w „tworzeniu” lub ,stosowaniu” prawa, czy także (czego nie determinuje ukończenie wyższych studiów prawniczych) o zatrudnienie na stanowiskach niewymagających umiejętności prawniczych (na przykład w zakresie obsługi technicznej, sekretarskiej, informatycznej bądź w służbach pomocniczych — bibliotece, elektronicznej bazie danych - instytucji tworzących lub stosujących prawo). Ponadto, w ocenie TK, użyte $\mathrm{w}$ kwestionowanym segmencie przepisu określenia nie sprecyzowały dostatecznie rodzaju wykonywanych czynności (skali ich związku merytorycznego z procesem „tworzenia” lub „stosowania” prawa), jak też nie wykluczyły osób zatrudnionych na stanowiskach o nader wąskim zakresie stosowania jednej dziedziny prawa (na przykład tylko celnego, podatkowego, budowlanego) $\mathrm{i}-\mathrm{w}$ konsekwencji — nader wąskich (fragmentarycznych) doświadczeniach zawodowych, jeśli oceniać je z perspektywy umiejętności niezbędnych do wykonywania zawodu radcy prawnego. Taka regulacja, nieodpowiadająca zasadzie określoności, rodzi zdaniem Trybunału ryzyko dowolnej interpretacji i uzasadnia zastrzeżenia co do zgodności kwestionowanej regulacji zarówno z art. 2, jak i z art. 17 ust. 1 Kon-

\footnotetext{
31 Zob. wyrok WSA w Warszawie z dnia 9 listopada 2017 roku, VI SA/Wa 1173/17.

32 Zob. wyrok WSA w Warszawie z dnia 7 czerwca 2018 roku, VI SA/Wa 575/18.

33 Zob. wyrok TK z dnia 8 listopada 2006 roku, K 30/06.
} 
stytucji ${ }^{34}$. Trzeba odnotować, że przedstawione wytyczne TK nie zostały w pełni zrealizowane w komentowanej regulacji, która wciąż posługuje się wspomnianym niejasnym pojęciem „związania” (więzi) oraz nie wyklucza prawników o nadmiernie wąskich specjalizacjach.

Swoje stanowisko TK doprecyzował w wyroku z dnia 7 marca 2012 roku (K 3/10) $)^{35}$ Przypomniał $\mathrm{w}$ nim, że świadczenie pomocy prawnej zgodnie $\mathrm{z}$ art. 7 u.r.p. polega między innymi na udzielaniu porad prawnych, sporządzaniu opinii prawnych, opracowywaniu projektów aktów prawnych oraz występowaniu przed urzędami i sądami. Mając to na względzie, zaznaczył, że osoby, o których mowa w art. 25 ust. 2 pkt 3 i 4 u.r.p., wykonują wymagające wiedzy prawniczej czynności wspierające (asystenckie); są to czynności bezpośrednio związane ze świadczeniem pomocy prawnej. TK stwierdził, że należy do nich przygotowywanie analizy akt sprawy, wyszukiwanie i gromadzenie orzecznictwa oraz literatury, sporządzanie ekspertyz prawnych pomocnych w świadczeniu pomocy prawnej, przygotowywanie projektów pism procesowych oraz czynny udział w ustalaniu strategii postępowania, która ma doprowadzić do uzyskania korzystnego dla strony rozstrzygnięcia. W ocenie Trybunału czynności te pozwalają na zdobycie odpowiedniej praktyki i doświadczenia w zawodzie prawniczym. Jak zaznaczył, ustawodawca wykluczył z kręgu wymaganych czynności prace, które nie pozwalają na zdobycie wymaganego doświadczenia prawniczego.

W świetle orzecznictwa TK przyjąć wypada, że wskazane czynności muszą dawać doświadczenie odpowiednie do wykonywania zawodu radcy prawnego ${ }^{36}$. Ponadto powinny być one wykonywane osobiście i w sposób ciągły ${ }^{37}$.

Między czynnościami wymagającymi wiedzy prawniczej wykonywanymi przez daną osobę a pomocą prawną świadczoną na rzecz zatrudniającego ją urzędu zachodzi związek bezpośredni, jeżeli osoba ta osobiście uczestniczy w różnorodnych czynnościach z zakresu procesu pomocy prawnej realizowanego na rzecz tej jednostki, wnosząc $\mathrm{w}$ ten proces swój istotny wkład merytoryczny, a nie tylko uczestnicząc $w$ tym procesie wypadkowo, pomocniczo czy też pośrednio (na przykład $w$ ramach świadczenia umowy z agencją pracy) ${ }^{38}$. Tym samym art. 25 ust. 2 pkt 4 u.r.p. jako ustanawiający wyjątek od zasady nie może być interpretowany rozszerzająco, a ponadto nie można dokonywać jego wykładni wyłącznie

34 Podobnie w wyroku TK z dnia 19 kwietnia 2006 roku, K 6/06, OTK ZU 2006, seria A, nr 4, poz. 45 z glosą aprobującą P. Sarneckiego, „Przegląd Sejmowy” 2006, nr 5, s. 146-149.

35 OTK 2012, seria A, nr 3, poz. 25.

36 Zob. zawarte w wyroku z dnia 19 kwietnia 2006 roku, K 6/06, stwierdzenie TK, że „Wątpliwości może wzbudzić — w ocenie Trybunału Konstytucyjnego — objęcie dopuszczeniem do zawodu adwokata osób z odbytą aplikacją i zdanym egzaminem prokuratorskim oraz notarialnym, przede wszystkim ze względu na istotną odmienność zakresu przedmiotowego kształcenia oraz zróżnicowanie profilu w powinnościach zawodowych odpowiednio: adwokata i prokuratora oraz notariusza".

37 Zob. wyrok TK z dnia 18 kwietnia 2006 roku, K 6/06.

38 R. Stankiewicz, op. cit., s. 439-441. 
w płaszczyźnie literalnej, ale należy jej dokonać w powiązaniu z celem odbycia aplikacji radcowskiej, z której następuje zwolnienie ${ }^{39}$.

Zgodzić się należy, że pojęcie „czynności bezpośrednio związanych ze świadczeniem pomocy prawnej na rzecz [...] urzędów" użyte w treści art. 25 ust. 2 pkt 4 u.r.p. nie dotyczy jedynie czynności dokonywanych na wewnętrzne potrzeby urzędów i nie wyklucza czynności orzeczniczych. Sposób oddziaływania tych czynności - czy „na zewnątrz”, czy na potrzeby wewnętrzne organu — zależy od funkcji danego urzędu organu władzy publicznej ${ }^{40}$. Należy zaznaczyć, że częstokroć świadczenie pomocy prawnej na rzecz urzędu polega na formułowaniu dla niego lub w jego imieniu pism czy projektów skierowanych docelowo do podmiotów zewnętrznych. Odpowiada to usprawiedliwionemu oczekiwaniu, że działalność administracji nie będzie autoteliczna. Tym samym w zakresie omawianej normy mieści się świadczenie pomocy prawnej zarówno samemu urzędowi, jak i w jego imieniu (z jego woli) klientom urzędu.

\section{CZYNNOŚCI ZWIĄZANE Z TWORZENIEM PROJEKTÓW USTAW, ROZPORZĄDZEŃ LUB AKTÓW PRAWA MIEJSCOWEGO}

W odniesieniu do czynności związanych z tworzeniem aktów prawnych warto wskazać intencje wyrażone przez twórców ustawy w trakcie procesu legislacyjnego. Legislator M. Bies-Olak wyjaśniła bowiem, że

chodzi o umożliwienie przystąpienia do egzaminu bez obowiązku odbywania aplikacji legislatorom i osobom zatrudnionym w urzędach organów władzy publicznej lub w państwowych jednostkach organizacyjnych, które wykonywały czynności wymagające wiedzy prawniczej bezpośrednio związane z tworzeniem projektów ustaw, rozporządzeń lub aktów prawa miejscowego.

Z kolei zastępca dyrektora departamentu w Ministerstwie Sprawiedliwości M. Madurowicz wskazała, że projektodawca miał na myśli „bieżącą pracę przy tworzeniu aktów prawnych"41.

Orzecznictwo sądów administracyjnych wskazuje z kolei, że jakkolwiek literalnie odczytywane przepisy nie wymagają wprost, aby osoba ubiegająca się o wpis wykonywała wymagające wiedzy prawniczej czynności bezpośrednio związane z tworzeniem projektów ustaw i rozporządzeń lub aktów prawa miejscowego stale i nieprzerwanie, w ramach podstawowych obowiązków, przez cały wymagany okres, nie zaś jedynie incydentalnie bądź tymczasowo — to takie wymaganie wyni-

39 Ibidem, s. 439.

40 Zob. wyrok WSA w Warszawie z dnia 6 czerwca 2018 roku, VI SA/Wa 397/18 (nieprawomocny).

41 Zob. posiedzenie sejmowej Komisji Nadzwyczajnej do rozpatrywania projektów ustaw deregulacyjnych w dniu 3 stycznia 2013 roku, http://www.sejm.gov.pl/sejm7.nsf/biuletyn. xsp?documentId=375A1113BBC36E3CC1257AEF004D6D58. 
ka z wykładni systemowej przepisów ${ }^{42}$. Tworzenie projektów aktów normatywnych nie może być incydentalne, to jest być tylko jednym z licznych obowiązków, które wykonuje kandydat na radcę prawnego. Powinno to być zajęcie główne i wykonywane regularnie przez określony w ustawie czas (bez znaczenia, czy w wydzielonych jednostkach legislacyjnych, czy poza nimi), gdyż rozmiar tych czynności i ich intensywność powinna świadczyć, że dana osoba posiadła wiedzę stosowną do wykonywania zawodu radcy prawnego ${ }^{43}$. Niemniej rzeczywisty udział i rola wnioskodawcy w procesie stanowienia prawa musi być przedmiotem wnikliwego postępowania wyjaśniającego ze strony organu prowadzącego postępowanie ${ }^{44}$. Wnioskodawca musi wykazać, że miał bezpośredni wpływ na kształtowanie treści aktów normatywnych, nie zaś że jedynie przygotowywał materiały czy wytyczne będące podstawą ich opracowania ${ }^{45}$. Do czynności związanych bezpośrednio z tworzeniem projektów aktów prawnych nie zalicza się czynności nadzorczych czy organizacyjnych związanych z procesem legislacyjnym (na przykład omawiania projektów na posiedzeniach organów stanowiących $)^{46}$.

\section{WERYFIKACJA DOŚWIADCZENIA W WYKONYWANIU CZYNNOŚCI WYMAGAJĄCYCH WIEDZY PRAWNICZEJ}

TK w swoim orzecznictwie zaznaczył, że samorząd radców prawnych nie jest (nie może być) pozbawiony możliwości badania, czy konkretna osoba ubiegająca się o wpis na listę radców prawnych daje rękojmię należytego wykonywania zawodu. Jak wskazał, możliwy jest — także w świetle zasady wolności wyboru i wykonywania zawodu, ustanowionej w art. 65 ust. 1 Konstytucji - przepływ z jednego do innego zawodu prawniczego, co nie oznacza jednak, że przepływ taki ma następować automatycznie, bez oceny umiejętności niezbędnych do należytego wykonywania nowego dla danej osoby zawodu prawniczego ${ }^{47}$. Uwagę tę odnieść można nie tylko do zawodów prawniczych regulowanych ustawowo, ale do wszystkich przypadków wykonywania czynności wymagających wiedzy prawniczej. W warunkach obowiązywania konstytucyjnej zasady równości i równego

42 Por. wyrok WSA w Warszawie z dnia 27 października 2014 roku, VI SA/Wa 1370/14. W ocenie sądu w tej sprawie celem ułatwienia wpisu omawianą regulacją było objęcie nią wyłącznie legislatorów.

43 Zob. wyrok WSA w Warszawie z dnia 14 stycznia 2019 roku, VI SA/Wa 1625/18 (nieprawomocny); wyrok WSA w Warszawie z dnia 10 lipca 2015 roku, VI SA/Wa 4082/14. Por. też wyrok WSA w Warszawie z dnia 5 lipca 2016 roku, VI SA/Wa 496/16.

${ }_{44}$ Zob. wyrok NSA z dnia 2 sierpnia 2016 roku, II GSK 620/15.

45 Zob. wyrok WSA w Warszawie z dnia 20 lutego 2015 roku, VI SA/Wa 3564/14, od którego wniesiona skarga kasacyjna została oddalona wyrokiem NSA z dnia 6 kwietnia 2017 roku, II GSK 2675/15.

46 Zob. wyrok WSA w Warszawie z dnia 10 lipca 2015 roku, VI SA/Wa 4082/14.

47 Zob. wyrok TK z dnia 8 listopada 2006 roku, K 30/06. 
traktowania przesłankami oceny mogą być wyszkolenie oraz praktyczny kontakt $\mathrm{z}$ wykonywaniem danego zawodu wymagającego znajomości prawa ${ }^{48}$. TK akcentował potrzebę weryfikacji u osoby ubiegającej się o wpis znajomości aktualnie obowiązującego prawa oraz doświadczenia prawniczego, gdyż w odmiennym przypadku powstaje niebezpieczeństwo nienależytego wykonywania zawodu, które trudno pogodzić z art. 17 ust. 1 Konstytucji ${ }^{49}$. Środka ku temu upatrywał, podobnie jak doktryna ${ }^{50}$, przede wszystkim w egzaminie zawodowym ${ }^{51}$. Ponadto wskazał, że w państwie prawa organy dokonujące wpisu, a więc decydujące o przyznaniu uprawnienia, muszą w sposób wszechstronny zweryfikować istnienie ustawowych przesłanek przyznania tego uprawnienia także pod kątem ustalenia, czy dana osoba daje rękojmię należytego wykonywania zawodu, a przesłanką oceny winien być między innymi praktyczny kontakt z wykonywaniem zawodu. Przy czym organy samorządu zawodowego nie mogą rzecz jasna bezrefleksyjnie przedkładać interesu tego samorządu nad słuszny interes strony ${ }^{52}$.

Także NSA podkreślał, że praktyka zawodowa uprawniająca do wpisu musi być odpowiednia zarówno pod względem rodzaju, jak i warunków jej odbywania ${ }^{53}$.

NSA zaakceptował pogląd, że nawet osoba, która zdała egzamin radcowski po przystąpieniu do niego bez odbycia aplikacji radcowskiej, nie może oczekiwać od organu wpisowego, że okoliczności, które uprawniły ją do przystąpienia do egzaminu zawodowego, zostaną w każdym przypadku podobnie ocenione przez ten organ, jak tego dokonała komisja egzaminacyjna (jej przewodniczący) ${ }^{54}$. Zapatrywanie to, chroniące niewątpliwie pieczę samorządu radcowskiego nad osobami mającymi wykonywać zawód radcy prawnego, może jednak budzić wątpliwości z perspektywy zaufania obywatela do organów władzy publicznej (art. 2 Konstytucji, art. $8 \S 1$ k.p.a.. $)^{55}$. W państwie prawnym kwestia relacji między czynnością dopuszczenia do egzaminu radcowskiego (art. $33^{3}$ u.r.p.) osób zwolnionych z obo-

48 Zob. wyrok TK z dnia 19 kwietnia 2006 roku, K 6/06. Wskazano w nim, że kwestie te winien rozstrzygnąć jednoznacznie ustawodawca.

49 Zob. ibidem.

50 Zob. M. Szydło, Nabywanie uprawnień do wykonywania wolnych zawodów, „Państwo i Prawo" 2002, nr 7, s. 55-56.

51 Por. wyrok TK z dnia 7 marca 2012 roku, K 3/10.

52 Zob. wyrok NSA z dnia 2 sierpnia 2016 roku, II GSK 620/15.

53 Por. wyrok NSA z dnia 22 sierpnia 2012 roku, II GSK 1779/11.

54 Zob. wyrok NSA z dnia 9 kwietnia 2019 roku, II GSK 1721/18, w którym mając na względzie art. 17 Konstytucji, stwierdzono: „Warunki — spełnienie których jest wymagane także na etapie poprzedzającym przystąpienie do egzaminu — podlegają [...] ocenie przez organy samorządu radcowskiego także po złożeniu egzaminu w postępowaniu wszczętym wnioskiem o wpis na listę radców prawnych".

55 Zob. wyrok WSA w Warszawie z dnia 18 kwietnia 2018 roku, VI SA/Wa 150/18; wyrok WSA w Warszawie z dnia 11 kwietnia 2018 roku, VI SA/Wa 224/18, zwracające uwagę na zasadę wzbudzania zaufania do organów władzy publicznej (art. $8 \S 1$ k.p.a.) oraz zasadę ochrony praw nabytych. Wydaje się jednak, że zasada ochrony praw nabytych nie wchodzi tutaj w grę, gdyż nie są one w omawianym przypadku dostatecznie ukształtowane. 
wiązku odbycia aplikacji radcowskiej a wpisem na listę radców prawnych tych osób, które zdały egzamin radcowski, powinna zostać wprost określona przepisami prawa, skoro różnica między obiema czynnościami jest podmiotowa w odniesieniu do organów właściwych, tożsama jest zaś podstawa materialnoprawna.

Przytoczone uwagi judykatury mają jednak dalej idące konsekwencje. Rodzą bowiem pytanie, czy w ogóle rozwiązanie zakładające wpisanie osoby na listę radców prawnych bez złożenia przez nią egzaminu radcowskiego — to jest kategoria ujęta w art. 25 ust. 1 u.r.p. - jest zgodne z art. 17 ust. 1 Konstytucji. Wszak w tym przypadku organy samorządu radcowskiego nie mają wyraźnych narzędzi kontroli tego, czy osoba ubiegająca się o wpis daje rękojmię należytego wykonywania zawodu, a w razie jej braku do odmowy dokonania wpisu. Kwestia ta była podnoszona w postępowaniach przed TK, jednak lektura jego orzeczeń wskazuje początkowo na jej ominięcie ${ }^{56}$, a następnie jej zbycie przez stwierdzenie, że ocena rękojmi prawidłowego wykonywania zawodu radcy prawnego (art. 24 ust. 1 pkt 5 u.r.p.) obejmuje też kompetencje osoby ubiegającej się o wpis ${ }^{57}$, co nie odpowiadało praktyce NSA ${ }^{58}$ i pozostaje dyskusyjne ${ }^{59}$. Omówienie tego zagadnienia wykracza jednak poza ramy niniejszego opracowania, niemniej odczuwalny jest tu niedostatek regulacji ustawowej określającej dokładnie tryb, zakres i zasady weryfikacji owej szeroko rozumianej przez TK rękojmi. Jest on niepokojący zwłaszcza z perspektywy art. 2 i art. 7 Konstytucji, wszak organy samorządu radcowskiego — jako organy władzy publicznej — powinny mieć wyraźne podstawy swojej działalności i narzędzia sprawowania pieczy nad prawidłowym wykonywaniem zawodu radcy prawnego.

\section{UWAGI KOŃCOWE}

Ustawodawca nie sformułował, jako założenia generalnego, swobodnego „przepływu” między poszczególnymi zawodami prawniczymi ${ }^{60}$. Tym bardziej dotyczy to przepływu osób niewykonujących zawodów prawniczych regulowanych ustawowo, do których zasadniczo można zaliczyć urzędników. Dokonując oceny wypełnienia przesłanek, właściwy organ samorządu radcowskiego realizuje obowiązek sprawowania pieczy nad należytym wykonywaniem zawodu, w granicach interesu publicznego i dla jego ochrony ${ }^{61}$. Niemniej organy właściwe w sprawie

56 Zob. wyrok TK z dnia 18 kwietnia 2006 roku, K 6/06; wyrok TK z dnia 8 listopada 2006 roku, K 30/06.

57 Por. wyrok TK z dnia 7 marca 2012 roku, K 3/10.

58 Zob. wyrok NSA z dnia 7 lutego 2008 roku, II GSK 354/07; wyrok NSA z dnia 9 maja 2008 roku, II GSK 463/07.

59 Por. P. Kaczmarek, O rękojmi prawidłowego wykonywania zawodu adwokata oraz radcy prawnego, „Przegląd Prawa Publicznego” 2015, nr 1, s. 20-22.

60 Tak TK w wyroku z dnia 19 kwietnia 2006 roku, K 6/06.

61 R. Stankiewicz, op. cit., s. 392-393. 
wpisu na listę radców prawnych w istocie działają w warunkach związania ustawowego. Jak wyjaśnił to NSA, wpis na listę radców prawnych w przypadku osób, które nie spełniły wymogu odbycia aplikacji radcowskiej i złożenia egzaminu radcowskiego, zależy wyłącznie od wypełnienia przez wnioskodawcę określonych ustawowo przesłanek, a nie od swobodnego uznania organu administracji; ich wpis dopuszczalny jest jedynie w wyszczególnionych przez ustawodawcę sytuacjach. Ich wyliczenie nie ma charakteru przykładowego, lecz tworzy kata$\log$ zamknięty. Oznacza to, że tylko w przypadku zaistnienia i udokumentowania którejkolwiek z taksatywnie wymienionych w ustawie przesłanek faktycznych i prawnych możliwy jest (na wniosek zainteresowanego) wpis na listę radców prawnych. W innych przypadkach wniosek taki nie może być uwzględniony. Ustawa nie przewiduje bowiem żadnych wyjątków od ustanowionych w niej zasad ${ }^{62}$.

Jak wynika z przeprowadzonych badań, stan prawny odnoszący się do regulacji wpisu na listę radców prawnych osób wykonujących czynności wymagające wiedzy prawniczej w urzędach organów władzy publicznej nie jest zadowalający. Występują rozbieżności co do rozumienia pojęcia „zatrudnienia”, jak też wątpliwości wzbudza sama kategoria „urzędy organów władzy publicznej”. Ponadto sposób ujęcia w przepisach przesłanek wpisu na listę radców prawnych omawianej kategorii osób trudno uznać za w pełni urzeczywistniający ideały określoności i precyzji prawa. Stan ten nie współgra z wymogami art. 2 i art. 17 ust. 1 Konstytucji.

Dostęp urzędników do zawodu radcy prawnego jest w istocie dosyć wąski. Brakuje przesłanki w u.r.p. umożliwiającej wpis na listę radców prawnych bez weryfikacji w drodze egzaminu radcowskiego osób, które zdobyły stopień naukowy doktora nauk prawnych i istotne doświadczenie zawodowe w instytucjach publicznych na stanowiskach związanych z bieżącym stosowaniem prawa administracyjnego. $\mathrm{W}$ toku procesu legislacyjnego odrzucone zostały poprawki dotyczące poszerzenia podmiotowego zakresu osób uprawnionych do wpisu bez obowiązku zdania egzaminu radcowskiego i odbycia aplikacji radcowskiej o osoby wykonujące czynności związane ,z występowaniem przed sądami lub trybunałami, z wykładnią przepisów prawnych oraz analizowaniem orzecznictwa sądów i trybunałów do celów stosowania prawa" 63 . Tymczasem ta kategoria dotyczyłaby przede wszystkim właśnie urzędników. Rozszerzenie istniejącego katalogu wyłącznie w drodze wykładni o takie osoby jest niewątpliwie niedopuszczalne ${ }^{64}$. Istniejącego stanu rzeczy nie sposób w pełni zaaprobować — i to nie tylko ze

62 Zob. wyrok NSA z dnia 14 lutego 2019 roku, II GSK 5672/16.

${ }^{63}$ Zgłaszane jako wnioski mniejszości przez posłów P. Wiplera i K. Pawłowicz, zob. sprawozdanie Komisji Nadzwyczajnej do rozpatrzenia projektów ustaw deregulacyjnych o rządowym projekcie ustawy o zmianie ustaw regulujących wykonywanie niektórych zawodów (druk nr 806), druk sejmowy Sejmu VII kadencji nr 1166. Zob. też posiedzenie sejmowej Komisji Nadzwyczajnej do rozpatrywania projektów ustaw deregulacyjnych w dniu 7 lutego $2013 \mathrm{roku}$, http://www.sejm. gov.pl/sejm7.nsf/biuletyn.xsp?skrnr=NDR-7.

64 Zob. wyrok WSA w Warszawie z dnia 14 stycznia 2019 roku, VI SA/Wa 1625/18. 
względu na przedstawione w analizie wątpliwości co do urzeczywistnienia zasady równości, lecz także ze względów prakseologicznych. Tworzy on wszak przeszkodę do wpisu na listę radców prawnych bez konieczności zdania egzaminu radcowskiego wybitnych, mających wykształcenie prawnicze wieloletnich specjalistów z zakresu prawa administracyjnego, których wiedza naukowa została do tego potwierdzona w postępowaniu zakończonym nadaniem stopnia naukowego doktora nauk prawnych. Tymczasem mogliby oni owocnie świadczyć skuteczną pomoc prawną w sprawach, w których zdobyli tak szerokie doświadczenie administracyjne i prawne. Owo doświadczenie mogłoby być też z korzyścią wykorzystane w działalności samego samorządu radcowskiego. Szersze dopuszczenie urzędników do zawodu radcy prawnego niż do zawodu adwokata odpowiadałoby różnicy między tymi zawodami. Niemniej poszerzenie o te osoby wyjątków od konieczności zdania egzaminu radcowskiego wymagałoby zmiany brzmienia omawianych przepisów przez precyzyjne uzupełnienie art. 25 ust. 1 u.r.p. o kategorię doświadczonych urzędników - na przykład zajmujących stanowiska kierownicze w administracji lub prowadzących postępowania jurysdykcyjne (działalność orzeczniczą) z upoważnienia organu — ze stopniem doktora nauk prawnych. Dlatego warto $\mathrm{w}$ tym zakresie formułować postulaty de lege ferenda.

\section{PUBLIC OFFICIALS' ENTRY TO THE LIST OF ATTORNEYS-AT-LAW - PROBLEMATIC ISSUES}

Summary

This article concerns problems on the movement of people employed in public administration to the National Bar of Attorneys-at-Law. The legal framework relating to the regulation of the entry into the list of attorneys-at-law of persons performing activities that require legal knowledge in offices of public authorities is not satisfactory. There are discrepancies in the understanding of the notion of "employment". There are also doubts raised concerning the category of "offices of public authorities". Moreover, the manner in which the provisions set out the prerequisites for entry on the list of attorneys-at-law of the discussed category of persons does not implement the ideals of legal clarity and precision. This is not in line with the requirements of Article 2 and Article 17.1 of the Constitution. De lege ferenda, persons who have a $\mathrm{PhD}$ degree in law and significant, long-term professional experience related to the current application of administrative law in public institutions should be allowed to enter into the list of attorneys-at-law without the need to take the bar exam.

Keywords: the National Bar of Attorneys-at-Law, public officials, attorneys-at-law 


\section{BIBLIOGRAFIA}

Gersdorf M., Prawo zatrudnienia, Warszawa 2013.

Kaczmarek P., O rękojmi prawidłowego wykonywania zawodu adwokata oraz radcy prawnego, „Przegląd Prawa Publicznego” 2015, nr 1.

Nowak I., Bucholski R., Dostęp doktorów nauk prawnych do zawodów prawniczych - wybrane problemy, „Zeszyty Naukowe Sądownictwa Administracyjnego” 2015, nr 6.

Stahl M., Zagadnienia ogólne, [w:] System Prawa Administracyjnego, t. 6. Podmioty administrujace, red. R. Hauser, Z. Niewiadomski, A. Wróbel, Warszawa 2011.

Stankiewicz R., [w:] Ustawa o radcach prawnych. Komentarz, red. T. Scheffler, Warszawa 2018.

Szydło M., Nabywanie uprawnień do wykonywania wolnych zawodów, „Państwo i Prawo” 2002, nr 7.

Wajda P., Wiktorowska A., Agencje administracyjne, [w:] System Prawa Administracyjnego, t. 6. Podmioty administrujace, red. R. Hauser, Z. Niewiadomski, A. Wróbel, Warszawa 2011.

Ziółkowski M., Zasada równości w prawie, „Państwo i Prawo” 2015, nr 5. 